\title{
Studies on decolorization of textile dye by using Pseudomonas and Bacillus sp from the contaminated effluent soil samples of Kovilpatti, Thoothukudi district of Tamil Nadu
}

\section{Kannan}

K.R. College of Arts and Science, Affliated to Manonmaniam Sundaranar University, Tirunelveli (Tamil Nadu), India

Renuga Devi

K.R. College of Arts and Science, Kovilpatti, (Tamil Nadu), India

\section{A. G. Murugesan}

Manonmaniam sundaranar University, SPK Centre for Environmental Sciences, Alwarkurichi, (Tamil Nadu), India

S. Rajan*

M.R. Government Arts and Science College, Mannarkudi, (Tamil Nadu), India

*Corresponding author. E-mail: ksrajan99@gmail.com

\begin{abstract}
Textile industries releasing large amount of effluent which contains textile dyes and toxic chemicals and it is one of the major source of pollution also contaminating water bodies. To remove that, bacteria have been of great attention because of their ability to treat effluent. The present study was undertaken to exploit the ability of Pseudomonassp and Bacillus sp from dye contaminated soil samples for bioremediation for dye effluent. Among the bacterial strains used in the study. Pseudomonas sp emerged out to be most potent decolorizer in comparison to Bacillus $\mathrm{sp}$ with the degree of decolorization of 90.0 $\%$. Thus, it was concluded that the Pseudomonas sp had highest color removing capacity from contaminated effluent soil samples.
\end{abstract}

Keywords: Bacteria, Dye effluent, Decolorization, FT-IR analysis, Spectrophotometer

\section{INTRODUCTION}

Synthetic dyes are polyaromatic, which gives permanent color to fabrics. Among the all synthetic dyes, Azo dyes are mostly used in textile industries and which has high affinity to bind with cellulosic fibre, stability, easiness, availability of colours and cost effectiveness of their synthesis (Singh et al., 2012; Babu et al., 2007). Most of the dyes do not bind to the textile fabrics and inefficiency during dyeing process, those unused dyestuff used to dispose into the environment. But these azo dyes are aromatic compounds but acute toxic to plants, microbes, other living things also affects aesthetic merit, obstructs light penetration, oxygen transfer, into the water bodies when it's released into the environment and recalcitrant to decolorization and degradation because dye effluent possesses benzene, anthraquinone, naphthalene, halogens, hydrocarbons, salts and other intermediate compounds (Pan et al., 2017; Birhanli and Ozmen, 2005; Couto, 2009). Moreover, some dyes may be decomposed to produce carcinogenic aromatic amines containing pyridine, cyanide, phenol and heavy metals such as mercury, cadmium, and chromium (Lumbaque et al., 2017). In the current

\section{Article Info}

DOI:10.31018/jans.v11i1.1980

Received: December 31, 2018

Revised: February 6, 2019

Accepted: February 17, 2019

\section{How to Cite}

Kannan, D. et al. (2019) Studies on decolorization of textile dye by using Pseudomonas and bacillus $\mathrm{sp}$ from the contaminated effluent soil samples of Kovilpatti, Thoothukudi district of Tamil Nadu. Journal of Applied and Natural Science, 11(1): 134-137 scenario, environmental pollution has a foremost problem in worldwide due to rapid industrialization and its impact on huge waste generation into the biosphere (Andre et al., 2007). The textile industries has generated huge waste such as heavy metals, dyes, chlorinated compounds to the environment by discarding dye effluents into the water bodies as well as soils due to that its necessary to develop the effective way to treat the effluent for degrading the dyes (Mansour et al., 2012). Several physical, chemical and photochemical methods have been used for the treatment of textile wastewater, but these methods are have some limitation including cost effective, huge amounts of sludge which requires safe disposal (USEPA, 2012). Discharge of textile effluent without appropriate treatment may lead to bioaccumulation that may incorporate into food chain and also effect to the human health. A number of microorganisms have been already reported regarding dye decolorization, Whereas biological methods have stable effects and low operation cost (Khalid et al., 2010). Keeping in view of the above background, the present study was focused on the screening and characterization of potent indige- 
nous bacterial isolates from textile dying effluents and utilization of these isolates as monoculture and consortium for decolorization of some commercially available textile reactive dyes as well as dye mixture.

\section{MATERIALS AND METHODS}

Sample collection: The untreated textile dye effluent soil sample were collected from dye contaminated soil resources from surroundings of dye industry in Kovilpatti, Tamilnadu, India, were used to isolate dye decolorizing bacteria. Effluent samples were collected by sterile screw-cap bottles and aseptically transported to the laboratory within an hour. The isolation of bacteria was carried out by serial dilution of the effluent sample in sterile distilled water and subsequently plated into Nutrient agar (Cappuccino et al., 1996).

Isolation of azodye degrading bacteria: For isolation of dye degrading bacteria, $0.1 \mathrm{ml}$ of waste water sample was spread on the sterile Nutrient agar (NA) plates and incubated at $37^{\circ} \mathrm{C}$ for $24 \mathrm{~h}$. After incubation, morphologically distinct and prominent colonies were picked up and purified through repeated streaking on the nutrient agar. The purified bacterial isolates were maintained in NA slants for further use at $4^{\circ} \mathrm{C}$.

Physiological and biochemical characterization: The physiological properties of selected isolates (Psudomonas $\mathrm{sp}$ and Baillus $\mathrm{sp}$ ) were tested for their ability to decolorize textile effluent and determined through standard procedures like motility test, Gram staining, spore staining, capsule staining. Bacterial cultures were characterized by making use of biochemical tests like Motility, IMViC, catalase test, oxidase, starch hydrolysis and $\mathrm{H}_{2} \mathrm{~S}$ using textual procedures.

Measurement of dye decolurization: Different concentrations of textile effluent were added into the nutrient broth $(10,20,30,40,50,60,70,80$, $90,100 \mathrm{ml}$ ) and $3 \mathrm{ml}$ of 24 hours selected isolate of Bacillus $s p$ were subsequently added into the nutrient broth. In another set of effluent treatment flask another selected isolate of Pseudomonas $\mathrm{sp}$ were added and control were maintained. All the conical flasks were kept for incubation along with

Table 1. Biochemical characterization of selected potent bacterial strains.

\begin{tabular}{llll}
\hline S.N. & Characteristics & S3 & S5 \\
\hline 1 & Gram's Staining & - & + \\
2 & Morphology & Rod & Rod \\
3 & Motility & - & - \\
4 & Spore staining & - & + \\
5 & Indole test & + & - \\
6 & Methyl red test & - & - \\
7 & Voges-Proskauer test & + & - \\
8 & Citrate test & + & + \\
9 & Catalase test & + & + \\
10 & Oxidase test & + & - \\
11 & $\mathrm{H}_{2}$ S production & - & - \\
\hline \hline
\end{tabular}

decolorization for 48 hours. After incubation, samples were subjected to centrifugation at 10,000 rpm for $15 \mathrm{~min}$. The supernatant was measured using spectrophotometer at 460 $\mathrm{nm}$. The efficiency of decolorization given in percentage (Sriram et al., 2013)

$$
\text { Decolorization }=\frac{\text { Initial absorbance- final absorbance }}{\text { Initial absorbance }} \times 100
$$$$
\text { ....Eq. } 1
$$

Fourier Transform-Infrared Spectroscopy analysis (FT-IR): Decolorized culture medium by microbial consortium was centrifuged at $7000 \mathrm{rpm}$ for $20 \mathrm{~min}$. The metabolites present in the culture supernatant were extracted using equal volume of Ethyl acetate (Shah, 2016).

\section{RESULTS AND DISCUSSION}

In the present study five different (S1, S2, S3, S4 and S5) dye contaminated samples were processed. The effluent contaminated soil samples were collected from local field of Kovilpatti, Thoothukudi district. From these, S3 sample exhibited maximum bacterial isolates. Hence it was selected for further enumeration process. Murthy et al., (2012) documented six bacterial isolates from dye contaminated soil samples of Ahmedabad, Gujarat. Out of these, who also stated that SpNB6 expressed maximum (85\%) decolourization deficiency against azo dye A total of 20 bacterial isolates (SB1- SB20) were enumerated by sterile Nutrient agar. Based on the morphological distinct characteristics, only two isolates S3 (Pseudomonas sp) and S5 (Bacillus sp) were selected for further taxonomical studies. Similarly Liu et al (2017) studied the characterization of methyl orange decolorizing isolate namely strain Bacillus circulans BWL1061 from salt plan and also he reported the efficiency of decolorization of the strain was $50 \mathrm{mg} / \mathrm{L}$ methyl orange and $50 \mathrm{mg} / \mathrm{L}$ of chromium under anaerobic condition with the presence of $60 \mathrm{~g} / \mathrm{L}$ sodium chloride.

Many researchers focus on the utilization of microbial catalysts to remove die from the effluent. Especially bacterial decolorization and degradation of Azo dyes has been of considerable interest since it achieves a higher degree of biodegradation and mineralization is applicable to a wide variety of azo dyes (Pan et al., 2017). Khan and Srivastava (2014) isolated and identified five types of bacterial strains namely $\mathrm{KN} 1, \mathrm{KN} 2, \mathrm{KN} 3, \mathrm{KN} 5$, KN6 for textile dye decolorization process from rhizosphere region of garden soil and reported that among the five strains KN3, KN5 and KN6

Table 2. Decolorization ability of azo dye using selected potent bacterial strains.

\begin{tabular}{lll}
\hline $\begin{array}{l}\text { Concentration } \\
\text { of Dye (ppm) }\end{array}$ & OD (460nm) & $\begin{array}{l}\text { Percentage of } \\
\text { decolorization }\end{array}$ \\
\hline $\begin{array}{l}\text { Pseudomonas } \\
\text { Bacillus }\end{array}$ & 0.035 & $90 \%$ \\
\hline
\end{tabular}


Kannan, D. et al. / J. Appl. \& Nat. Sci. 11(1): 134-137 (2019)

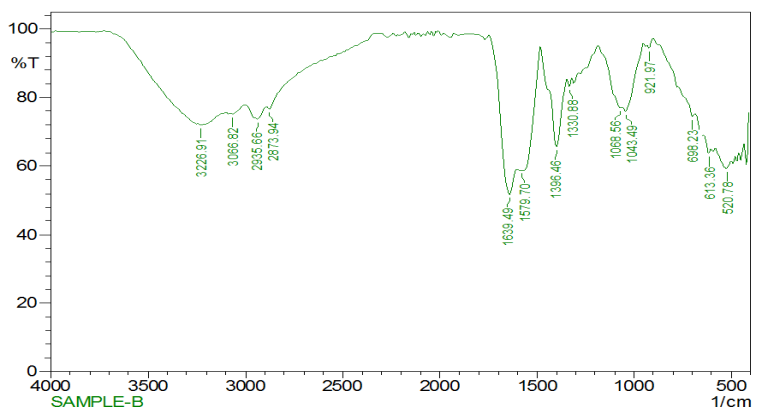

Fig. 1. FT-IR spectral analysis of dye decolorization ability of potent Pseudomonas $s p$.

shows maximum ability of decolorization against methyl orange.

Identification of selected potent strain: The selected two bacterial (S3, S5) isolates characterized by using standard procedures and the results are represented in Table 1 which expressed both strains appeared as rod shape, non-motile and showed negative results for $\mathrm{H}_{2} \mathrm{~S}$ production and methyl red reduction test. One of the isolate S3 exhibited Gram negative, Non - spore forming family organism and also expressed positive results for indole, Voges-Proskauer, citrate utilization, catalase and oxidase test. The selected bacterial strain S5 exhibited as Gram Positive and spore forming organisms and respectively showed the positive result for citrate utilization test.

Likewise Khan and Srivastava (2014) studied the biochemical characterization of six different (KN1, $\mathrm{KN} 2$...KN6) bacterial isolates through standard procedure. They also observed that all the six bacterial isolates showed positive results for oxidase test and carbohydrate fermentation test and casein hydrolysis test. Based on the results, a dominant strain was selected and identified as Pseudomonas sp. through Bergey's manual of systemic bacteriology. Based on the characterization part of this study the two isolates were identified as Pseudomonas sp. (S3) and Bacillus sp. (S5) respectively. Similarly dye decolorizing microorganisms Bacillus circulans was isolated and identified up to species level through standard procedure by Liu et al (2017).

Decolorization of Dye: The degradation efficiency of the study using the selected bacterial strains Bacillus $\mathrm{sp}$ and Pseudomonas $\mathrm{sp}$ were determined by spectrophotometric assay method and results are described in the table 2. It is expressed that the highest degree of decolorization (90\%) was observed using Pseudomonas sp and another bacterium Bacillus sp exhibited the degree of decoulrization is $82 \%$ using 5 ppm of Azo dye. Extensive studies have been carried out to determine the role of diverse groups of bacteria in the decolorization of azo dyes (Pandey et al., 2007). Likewise, Carliell et al (1996) and Razo - Flores et al., (1997) have associated the decolurization with methonogens, whereas studies by other in- vestigation showed that acidogenic as well as methonogenic bacteria contribute to dye decolurization with the degree of decolourization $62 \%$ and $2 \%$ respectively.

FT-IR Analysis: The FT-IR spectrum of the decolorization effect using the candidate strains was analyzed and the results are represented in Fig. 1. It expressed that the basic functional groups were observed in between the wavenumber of 3226.91 and $520.78 \mathrm{~cm}^{-1}$. The FTIR spectrum of dye decolorizing sample displayed a peak with the wavenumber of $3226.91 \mathrm{~cm}^{-}$ 1 exhibited the intramolecular hydrogen bonding aromatic $-\mathrm{OH}$ and $\mathrm{O}-\mathrm{H}$ stretching; a peak at $2,935 \mathrm{~cm}^{-1}$ expressed $\mathrm{C}-\mathrm{H}$ stretching of alkyl acetals and a peak at $2,873 \mathrm{~cm}^{-1}$ denoted $\mathrm{N}-\mathrm{H}$ stretching of amines; a peak at $1639 \mathrm{~cm}^{-1}$ showed $\mathrm{C}=\mathrm{N}$ stretching of alkane group; a peak with the wavenumber of $1,068 \mathrm{~cm}^{-}$ ${ }^{1}$ expressed $\mathrm{S}=\mathrm{O}$ stretching of sulfonic acid; a peak with the wavenumber of 921.00 and $613.36 \mathrm{~cm}^{-1}$ described aromatic nature and C$\mathrm{Cl}$ stretching, respectively. Notably there was absence of the peak responsible for azo (NON) group proposing that removal of azo bond after dye decolorization (Yu and Wen, 2005) Overall both these analytical study point out that there was structural degradation of the dye molecule which leads to the decolorization.

\section{Conclusion}

The results, thus obtained the efficiency of Pseudomonas sp (S3) and Bacillus sp (S5) for decolorization of azo dyes and to tolerate at high concentration gives an advantage for treatment of textile industry effluent. Current investigation confirmed that efficiency of maximum decolorization obtained by Pseudomonas sp under ideal condition was $90 \%$ and by Bacillus sp was $82 \%$. The results of the present study indicated that Bacillus sp., and Pseudomonas sp., can be used for the treatment of effluent contaminated waters.

\section{ACKNOWLEDGEMENTS}

The authors thank the Management and the Principal of K.R. College of Arts and Science, Kovilpatti, Tamil Nadu for their moral support.

\section{REFERENCES}

1. Andre, B.D., Fransisco, J.C. and Jules, B.L. (2007). Review paper on current technologies for decolourization of textile effluent. Colourage, 40, 35-38.

2. Babu, B.R., Parande, A.K., Raghu, S. and Kumar, T.P.(2007). Cotton textile processing: waste generation and effluent treatment. The J. Cotton Sci. 11:141 $-153$

3. Birhanli, A., and Ozmen, M. (2005). Evaluation of the toxicity and teratogenity of six commercial textile dyes using the frog embryo teratogenesis assayXenopus," Drug chem.. Toxicol. 28: 51-65.

4. Cappuccino, J., and Sherman, N. (1996). Microbiolo- 
gy: A Laboratory Manual. The Benjamin Cummings Publishing Company Inc. California.

5. Carliell, C.M., Barclay, N. and Buckky, C. A. (1996). Treatment of exhausted reactive dye both effluent using anaerobic digestion laboratory and full-scale trails water SA. 22, 225-233.

6. Couto, S.R. (2009). Dye removal by immobilised fungi. Biotechnology Advances, 27(3): 227-235.

7. Khalid, A., Kausar, F. and Arshad, M. (2012). Accelerated decolorization of reactive dyes under saline conditions by bacteria isolated from Arabian seawater sediment. Appl. Microbiol Biotechnol, 96:1599606

8. Khan, Kamaran Ali and Sweta Srivastava, (2014). Decolorization and degradation of textile dyes by bacterial isolates. Res. Environ.Life.Sci, 7(4):299-304

9. Liu, W., Liu, C. and Liu, L. (2017). Simulataneous decolourization of sulfonated azo dyes and reduction of hexavalemt chromium under high salt condition by a newly isolated salt tolerant strain Bacillus circulans BWL+061. Ecotoxicology and Environmental Safety.

10.Lumbaque, E.C., Gomes, M.F. and Carvalho, V.D. (2017). Degradation and ecotoxicity of dye Reactive Black 5 after reductive oxidative process. J. Environmental Science and Pollution Research 2017, 24(7): 6126-34

11.Mansour, H.B. (2012). Alteration of in vitro and acute in vivo toxicity of textile dyeing wastewater after chemical and biological remediation. Environmental Science and Pollution Research International, 2-7

12.Murthy Srinivas, D., Patel Suhagi, D., Soni Rakesh, and Bhatt Nikhil. (2012). Isolation and identification of bacterial culture for Azo dye degrading capability.
International Journal of Research in Chemistry and Environment, 2(4): 69-79.

13.Pan, F., Yu, F. and Xu, A.(2017). Application of Magnetic OMS-2 in sequencing batch reactor for treating dye wastewater as a modulator of microbial community. Journal of Hazardous Materials, 340:36-46

14.Pandey, A., Singh, P. and lyengar, L. (2007). Bacterial decolorization and degradation of Azo dyes. Int. Biodetoriation and Biodegradation. 59: 73-84.

15.Razo- Flores, E., Luijten, M., Donlon, B., Lettinga, G. and Field, J. (1997). Biodegradation of selected azo dyes under methanogenic conditions. Water, Science and technology, 36: 65-72.

16.Singh, P., lyengar, L. and Pandey, A. (2012). Bacterial Decolorization and Degradation of Azo Dyes. In: Microbial Degradation of Xenobiotics, Singh, S.N. (Ed.). Chapter 4, Springer, New York, ISBN: 978-3-642-23788-1:101-133.

17.Sriram, N., Reetha, D. and Saranraj, P. (2013). Biological degradation of reactive dyes by using bacteria isolated from dye effluent contaminated soil. Middle. East Journal of Scientific Research, 17(12):16951700

18.Shah, K.R., (2016). FTIR analysis of polyhydroxyalkanoates by novel Bacillus sp AS 3-2 from soil of Kadi region, North Gujarat, India

19.USEPA, (2012). Environmental Protection Agency. National Primary Drinking Water Regulations. http:// www.biovir.com/lmages/pdf054.pdf (accessed 27 September 2012).

20.Yu, Z. and Wen, X. (2005). Screening and identification of yeast for decolorizing synthetic dyes in industrial waste water, Int. Biodeter. Biodeg.r, 56; 109-114. 